Canadian Studies in Population, Vol. 33.1, 2006, pp. 83-117

\title{
Marriage and Cohabitation: \\ Demographic and Socioeconomic Differences in Quebec and Canada
}

\author{
Don Kerr \\ Department of Sociology \\ King's University College \\ University of Western Ontario \\ London, Ontario, Canada \\ Melissa Moyser \\ Department of Sociology \\ University of Toronto \\ Toronto, Ontario, Canada

\section{Roderic Beaujot} \\ Department of Sociology, \\ University of Western Ontario \\ London, Ontario, Canada
}

\begin{abstract}
Cohabitation has become so prevalent in Canada that it is now the most common mode of entry into conjugality. Yet in drawing comparisons across Canadian provinces, cohabitation is far more prevalent in the province of Quebec than elsewhere. With this in mind, the purpose of the current paper is three fold. First, we set out to briefly situate the recent growth in the number of common-law unions in Canada and Quebec into a broader historical and international context. Secondly, we review available information from the 2001 Census and the 1998 General Social Survey on some of the key socioeconomic and demographic characteristics of persons who cohabit relative to those that marry. Thirdly, we consider how these changes are important to public policy, and of direct interest
\end{abstract}


Don Kerr, Melissa Moyser and Roderic Beaujot

to legislators and the Canadian legal system. Major differences are documented in comparing Quebec with elsewhere in Canada in terms of the education, labor force participation, median income, income poverty and homeownership. The differences documented between persons who marry relative to cohabiters are found to be much less in Quebec than elsewhere, in a context whereby cohabitation has become far more widespread, an observation with direct implications for public policy.

Key Words: Common law unions, education, income, poverty, labour force participation

\section{Résumé}

La cohabitation est devenue tant prévalente au Canada qu'elle représente actuellement le mode d'entrée dans la vie conjugale le plus répandu. Cependant, quand on compare entre les provinces canadiennes, la cohabitation est beaucoup plus prévalente dans la province de Québec que dans le reste du pays. En tenant compte de ce fait, cet article a les trois buts suivant: Premièrement, nous donnons un bref aperçu de la récente hausse du nombre d'unions de fait dans son plus large contexte historique et international; deuxièmement, nous révisons l'information recueillie par le Recensement de 2001 et l'Enquête sociale nationale de 1998 au sujet de certaines caractéristiques socioéconomiques et démographiques clés des personnes qui cohabitent vis à vis de celles qui se marient ; troisièmement, nous examinons le pourquoi et le comment de l'importance de ces changements pour les politiques publiques et leur intérêt direct pour les législateurs et le système juridique canadien. Les différences majeures qui existent entre le Québec et le reste du Canada sont documentées quant aux niveaux d'éducation, de participation à la population active, de revenu moyen, de pauvreté de revenu et de propriété foncière. Il a été trouvé que les différences documentées entre les personnes qui se marient vis à vis celles qui cohabitent sont beaucoup moins importantes au Québec qu'ailleurs au pays et ce dans un contexte où la cohabitation y est devenue beaucoup plus répandue; une observation qui comporte des implications directes pour les politiques publiques.

Mots-clés: Les unions de fait, l'éducation, le revenu, la pauvreté, la participation à la population active 
Marriage and Cohabitation: Demographic and Socioeconomic Differences in Quebec and Canada

\section{Introduction}

In compiling international statistics on cohabitation, Kiernan (2002) has pointed to some rather important differences across societies. At one extreme are the Nordic countries of Western Europe (Sweden, Norway and Denmark) that now have very low marriage rates and very high levels of cohabitation. Clearly more formal relationships are being widely replaced by less formal relationships, as cohabitation has come to serve as a basis for family life (including childbearing). In contrast, in drawing comparisons across several EU countries, the common-law relationship continues to be relatively rare in other parts of the continent - as for example, cohabitation rates are particularly low in both Italy and Spain. As an example, whereas almost one third of all couples in Sweden are cohabiting (30 percent in 2000), this applies to fewer than 1 to 2 percent of Italian and Spanish couples.

In Canada, the cohabitation rate falls somewhere in between these two extremes - at 16 percent in 2001 (Statistics Canada, 2003). Yet in drawing generalizations, it is important not to lose sight of the fact that there are some rather striking differences in the popularity of cohabitation across different regions of the country. For example, according to the 2001 Canadian Census, fully 29.8 percent of couples in Quebec were living common law (Statistics Canada, 2003), which is in fact now comparable to some of the Scandinavian countries of Northern Europe (Keirnan, 2002). Across all other provinces in Canada, the prevalence of cohabitation is much lower, at only about 12 percent in 2001 . In reference to Ontario, only about 9.4 percent of couples were in common-law relationship, which is not far from the 8.2 percent documented in the 2000 U.S. Census.

Understanding the meaning and character of cohabitation is obviously related to how widespread and socially acceptable it has become. Early on, common-law unions are known as a lifestyle choice lived by a small minority, while most men and women continue to marry directly before establishing a common household (Kiernan, 2002). This might be said to describe the situation in Canada in the 1960 s or early 1970 s. Eventually the same society comes to view the common-law relationship as a reasonable prelude to marriage, particularly for young adults, with the rationalization that such probationary periods provide for the opportunity to test and strengthen relationships prior to longer term commitment. This situation might be said to characterize much of Canada today, with the notable exception of Quebec (LeBourdais and Lapierre-Adamcyk, 2004). As cohabitation eventually becomes more widespread, couples begin to view cohabitation as more long term, which in turn, leads to much higher levels 
Don Kerr, Melissa Moyser and Roderic Beaujot

of fertility and greater stability in common law unions. This is clearly much more so the pattern in Quebec today than it is elsewhere in Canada (Wu, 2000; Turcotte and Bélanger, 1997). As Kiernan (2002) suggests, cohabitation and marriage eventually come to be viewed as almost interchangeable and very difficult to differentiate.

With this in mind, the purpose of the current paper is three fold. First, we set out to briefly situate the recent growth in the number of common-law unions in Canada and Quebec into a broader historical and international context. Secondly, we will review available information from the 2001 Census and the 1998 General Social Survey on some of the key socioeconomic and demographic characteristics of persons who cohabit relative to those that marry. Thirdly, we consider how these changes are important to public policy, and of direct interest to legislators and the Canadian legal system. With Canadian data, we examine differences in terms of education, labor force participation, median income, income poverty, homeownership, as well as the organization and division of domestic tasks.

As a matter of introduction, we find that the situation outside of Quebec more closely fits the broader North American pattern, whereby persons with less education, lower earnings and more uncertain economic prospects are more likely to be in a cohabiting type of relationship and less likely to marry (Bumpass and Lu, 2000; Smock and Manning, 2004). On the other hand, in Quebec where cohabitation is now very widely accepted and viewed as almost one and the same as marriage, cohabitation does not appear to be nearly as selective on these socioeconomic characteristics. As the meaning of cohabitation has shifted, the differences between those that marry relative to those that cohabit appear to have lessened somewhat. This holds implications for those that debate the extent to which marriage and common law unions be treated as one and the same under the law and in terms of social policy.

\section{Canada's Second Demographic Transition}

In documenting family change in Canada, reference is often made to two rather broad transitions (Beaujot, 1999). The first transition, which began in the $19^{\text {th }}$ century, was the rather pronounced decline in fertility and mortality that accompanied Canada's modernization. Whereas fertility declined through to the mid $20^{\text {th }}$ century (prior to witnessing an unanticipated baby boom) mortality decline continued unabated through to the present. The second transition, which occurred more recently, has involved some rather dramatic changes in the flexibility and stability of marital relationships (Lesthaeghe, 1995). 
Marriage and Cohabitation: Demographic and Socioeconomic Differences in Quebec and Canada

While the first transition brought with it smaller families, the second transition brought with it dramatic changes in the nature of marital relationships, manifested in terms of increased cohabitation, divorce and remarriage. The first transition occurred over an extended period although it was temporarily halted by the baby boom. The second demographic transition was much more rapid, from about 1960 through to the present, and only began in earnest toward the end of the baby boom era. The timing and stability of marital relationships began to shift during the 1960 s and 1970 s, as the total fertility rate in Canada returned to its longer term downward trend, and has since fallen to a near all time low of only 1.5 births per woman (Statistics Canada, 2004).

Table 1 provides summary statistics on family change for Canada overall for the period 1941-2002, which fit reasonably well this second demographic transition. This transition is marked by greater flexibility in entry into and exit from conjugal relationships, as evidenced by the pronounced rise in cohabitation and divorce. Even though most Canadians marry or will marry, the common-law union is increasingly challenging marriage as the preeminent context in which to pursue conjugality and, for a growing number of Canadians, parenthood. While many marriages last until death do them part, divorce is ever more defying the definition of marriage as a permanent arrangement. These changes in births, marriage, cohabitation and divorce have brought fewer children, but also a higher level of diversity in the living arrangements and family life of Canadians.

These data in Table 1 confirm the uniqueness of the 1950s as the peak of the baby boom, a period of marriage rush, and high proportions of persons married at least once in their lives. As relationships are now less permanent and more flexible, childbearing is often delayed, there are fewer births overall, and many children are born outside of legal marriage. Whereas early on in this second demographic transition, cohabitation largely affected pre-marital relationships (and subsequently delayed marriage and childbearing), demographers now debate the extent to which cohabitation has come to replace marriage rather than merely serve as a prelude to legal marriage (Bélanger and Dumas, 1997). As conjugal relationships have been altered, the level of diversity in the family has risen. Family life in Canada may or may not involve parents who are legally married to one another, just as it may or may not involve children who are biologically related to both parents. Step and blended family living arrangements are becoming increasingly common, as is childlessness - among both cohabiting and legally married couples.

As cohabitation has become more widespread, it is increasingly influencing post-marital relationships (i.e. remarriage on the event of divorce). Many men and women on the event of a divorce are hesitant to marry for a second time, and subsequently, cohabitation serves as popular alternative. Many step and 


\section{Don Kerr, Melissa Moyser and Roderic Beaujot}

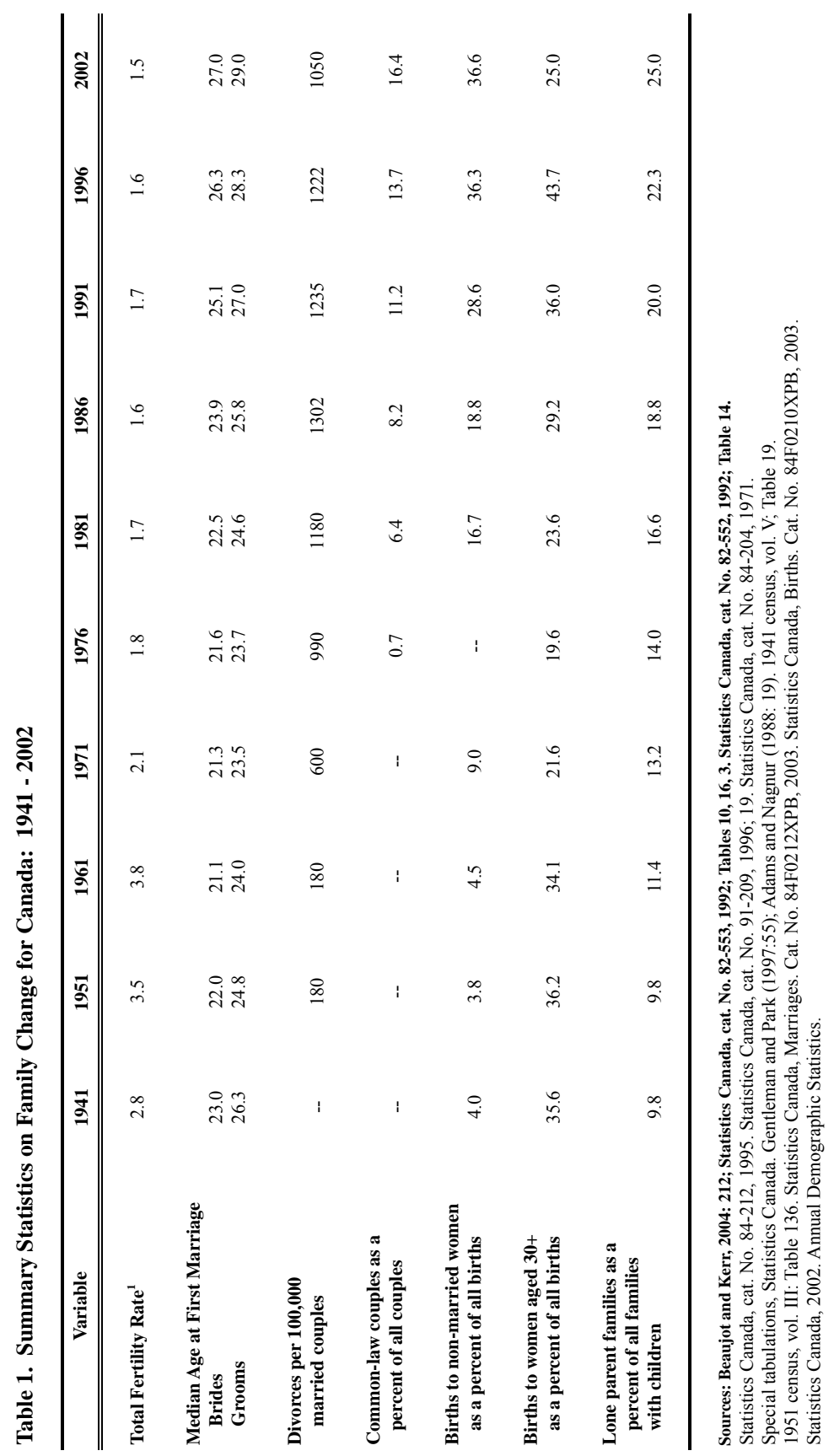


Marriage and Cohabitation: Demographic and Socioeconomic Differences in Quebec and Canada

blended families with children from previous marriages now involve commonlaw unions. That is, cohabitation first influenced pre-marital relationships, but now it affects post-marital relationships, and marriage itself. Regardless of all these changes, there is consensus that the prevalence of cohabitation is now a key indicator of family change.

\section{Cohabitation as the Modal Way to Enter Family Life}

While one might argue that there is nothing inevitable to these transitions (i.e. it is not inevitable that North Americans will follow Northern Europeans in terms of abandoning legal marriage for cohabitation), most demographers would argue that it is highly probable (Westoff, 1986; Hirschman, 1994; Ryder, 1983). Similarly, Ontario and other provinces in Canada are expected to eventually follow Quebec in terms of cohabitation, although the more difficult forecast in this context likely relates to the timing and pace of this partnership transition $(\mathrm{Wu}, 2000)$. In examining available time series on cohabitation in Canada, especially striking is the particularly rapid pace at which cohabitation became a popular alternative to marriage in the province of Quebec. In 1986, about 12 percent of Quebec couples were living common law - which is comparable to the percentage currently observed in Canada outside of Quebec.

While these figures indicate the percentage of all couples currently living common law, more detailed data from the General Social Survey (GSS) has demonstrated the very high incidence of cohabitation among younger age groups. While cohabitation is often very short lived and quickly converted into legal marriage, over half (53 percent) of all young women aged 20-29 years in 2001 could expect to live common-law as their first union (Statistics Canada, 2002). In Quebec, the probability of cohabitation is even higher - as over 4 out of 5 women in this same cohort could expect to do so (Le Bourdais and Juby, 2002). Similarly, among women aged $30-39$, it is estimated that about 70 percent in Quebec cohabit as a first union, while elsewhere in Canada, only about 34 percent do so. While we can appreciate that living common law implies a wide range of experiences, from little more than a dating type of arrangement through to a fully committed long term relationship (possibly with children), this option of cohabitation as a first union has become increasingly popular, and has actually become the modal way to begin family life in Quebec.

\section{Childbearing in Cohabitation}

While institutions other than the family have increasingly assumed many of the activities historically organized and performed in families, marriage has largely 
retained one of its most basic functions, i.e. the provision of a context for childbearing and childrearing (Wu, 2000: 88). Since this is widely considered one of the key dimensions of marriage, the extent to which childbearing occurs in common-law unions has often been thought of as a key indicator of the degree to which marriages and common law unions have become indistinguishable (Smock, 2000). The increase in extramarital fertility over the last twenty years has largely been the by-product of births to cohabiting couples (and less so the result of births to single women), and as a result, children are increasingly found in cohabitations (Ram, 2002). However, marriage continues to be the more common conjugal context in which to undertake childbearing and/or childrearing - although this appears to be changing rapidly - and is no longer true in the province of Quebec.

Between the early 1980s and 2000, the proportion of extramarital births in Canada increased from about one in six births overall to about one in three, an increase that has been largely attributable to births occurring to cohabiting couples (Le Bourdais and Lapierre-Adamcyk, 2004). In the early 1970s there was not much of a regional difference in childbearing by marital status, but by the latter 1990s, the differences were quite pronounced. For example, the proportion of children born in 1971-1973 to cohabiting parents and single mothers were comparable across regions, at 2-3 percent for cohabiters and 6-7 percent for single mothers. By 1997-1998, almost half of all births in Quebec were to cohabiting parents, and 9 percent to single mothers. Elsewhere in Canada, marriage continues to be the modal conjugal status, with only 15 percent born to cohabiting parents and 10 percent to single mothers.

The relatively low level of childbearing to non-married women outside of Quebec is certainly consistent with the idea that extramarital fertility has yet to achieve a particularly high level of social acceptance. Most children continue to be born to married couples, albeit a significant proportion of these marriages were predated by cohabitation. The common law union continues to be viewed as a reasonable prelude to marriage, yet unlike in Quebec, not the appropriate context for childbearing and the raising of children. Childbearing outside of marriage may actually continue to be stigmatized to a certain extent in English Canada, whereas in Quebec, the need to sanction a relationship through marriage prior to the birth of a first child appears to be increasingly irrelevant to the life course of young adults (Le Bourdais and Lapierre-Adamcyk, 2004).

Le Bourdais and Lapierre-Adamcyk (2004) have noted that for cohabitation to truly be an alternative to marriage, it must be an acceptable conjugal context in which to bear children as well as an enduring arrangement in which to rear children. In this regard, it is noteworthy that cohabiters with children outside of Quebec are five times more likely to separate than those headed by couples who 
Marriage and Cohabitation: Demographic and Socioeconomic Differences in Quebec and Canada

married directly, while among those in Quebec, cohabiters with children are only two and a half times more likely to do so. Children of cohabiting parents, then, face an elevated risk of family instability, but this is more so the case in Canada outside of Quebec. That families involving cohabiting couples are more stable in Quebec than in Canada outside of Quebec is therefore further evidence that it has become a more enduring conjugal arrangement that is increasingly viewed as a real alternative to the institution of marriage. This is consistent with Cherlin's (2004) argument that the quality and stability of cohabiting relationships seems to converge as cohabitation becomes more widespread and institutionalized.

\section{Comparing Cohabitation and Marriage}

As we have seen, international research has demonstrated how there are major differences in both marriage and cohabitation across societies and over time. In some societies, cohabitation continues to be largely viewed as merely a prelude to marriage, whereas in others, cohabitation has come to be viewed as almost indistinguishable from marriage (at least to the casual observer). In the Canadian context, Le Bourdais and Lapierre-Adamcyk (2004) have suggested that cohabitation in Quebec is closer to this latter situation (i.e. marriage and cohabitation becoming indistinguishable) whereas elsewhere in Canada the situation more closely fits the broader North American pattern (i.e. cohabitation as a childless prelude to formal marriage).

This inference is largely, yet not entirely, based on the widespread incidence of cohabitation in Quebec relative to other parts of the country. In this context, the current paper moves on to consider differences between cohabiters and married persons in terms of educational attainment, labour force participation, median income, income poverty, homeownership and the division of labour within the home. As different regions of Canada are distinct in terms of this "relationship transition", we look at these differences separately for Quebec and the rest of Canada.

\section{Educational Attainment}

While there has been considerable research on the socioeconomic characteristics of common law unions in the broader international literature, much less has been done on this topic in Canada. In reference to research in the United States, Seltzer (2004) has emphasized that cohabitation is in fact more common among those with less education, lower earnings and more uncertain economic prospects. In explanation, this has linked to the fact that marriage is often 
defined by its longer term economic responsibilities - which would obviously be somewhat more difficult for less educated men and women. Smock and Manning (2004) have argued that men's education and economic prospects in particular are very important determinants of whether a cohabiting couple would marry.

There is a clear gradient in comparing the educational attainment of cohabiters with married persons, with married persons systematically reporting a higher level of formal education obtained.

While American research has documented an educational gradient in comparing cohabiters and married persons, Canadian research is not as clear on this issue. For example, Smock and Gupta (2002) have reported that no such educational gradient exists in Canada, which would depart from this broader North American pattern. Turcotte and Goldschielder (1998) have indicated that while such a gradient exists, it currently exists solely for women, and its strength and even direction has not remained constant over time. For example, among Canadian women, the impact of education appears to have reversed itself over the last 20 years or so - from a situation whereby a higher education increased the likelihood of cohabitation to one whereby a higher education increases the likelihood of marriage (as opposed to cohabitation). In other words, educated women become less rather than more likely to cohabit, and more rather than less likely to marry.

This latter observation is consistent with some of basic descriptive statistics on educational attainment as available in the 2001 Census (see Table 2) - as cohabiting women are found to have lesser of an education than married women, a generalization which is true across most of the subsamples identified in Table 2. More specifically, Table 2 provides information on educational attainment of men and women separately, at similar stages of their life cycle (as defined by marital status, age and the presence of children). These statistics are shown for cohabiting or married adults, who are classified as (i) aged 18-29 with no children (ii) aged 30-39 years with no children, (iii) aged 40-59, with no children, (iv) any age, with at least one child under 6 years, (v) any age, with a youngest child aged 6-14 years, and (vi) any age, with a youngest child aged 1524. ${ }^{1}$ Educational attainment is examined separately for Quebec and the rest of Canada (ROC). While this education gradient might not be quite as large in Canada as it is in the United States, Table 2 does suggest that it exists particularly outside of Quebec. ${ }^{2}$

Very briefly, across nearly all categories in Table 2, persons who are in common-law unions have less of a formal education whereas persons who marry seem to be somewhat better educated. Across most categories, regardless of 
Marriage and Cohabitation: Demographic and Socioeconomic Differences in Quebec and Canada

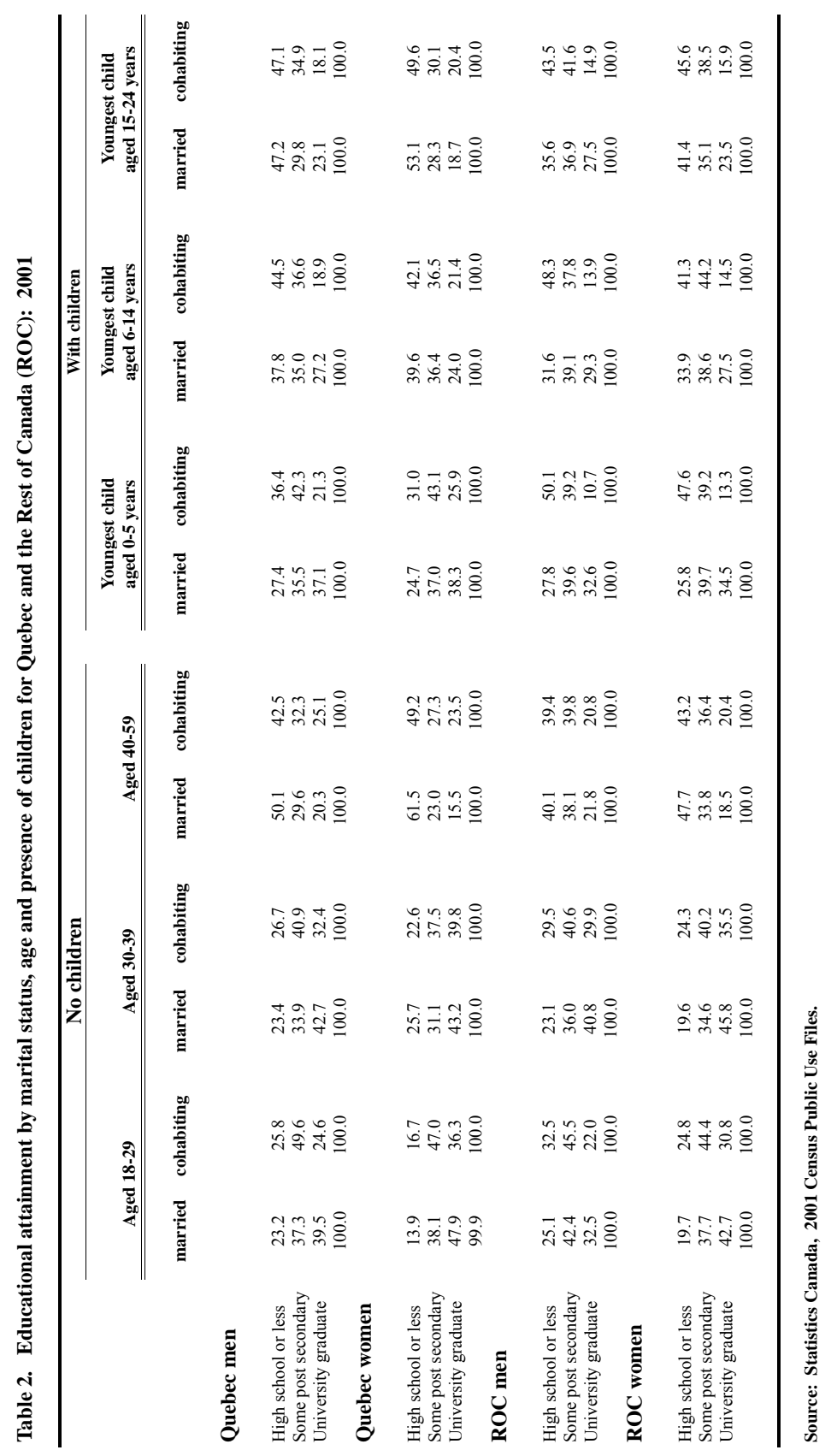


whether we focus on Quebec or elsewhere, those that marry have a better education, are more likely to report a university education and are less likely to have only a high school education - or less. For persons at certain stages of their life cycle, some of these differences are quite pronounced, as for example, among both cohabiting men and women outside of Quebec who are raising young children (aged 0-5 years). Among men with young children (aged 0-5) about 50.1 percent of cohabiting men have only a high school education, whereas among married men, 27.8 percent report an equivalent level of formal education. Similarly among women, fully 47.6 percent of cohabiters have high school or less, which compares with only 25.8 percent of married women.

In Quebec, a similar sort of situation seems to exist, although the differences are not nearly as pronounced. Among cohabiting men 36.4 percent are reported to have only a high school education, whereas among the married, 27.4 percent report this level of education. Similar differences are observed if we shift our attention to women with young children, as for example, 31.0 of cohabiters report high school or less, which compares with 24.7 percent of married women. To the extent that an educational gradient exists in Canada, it is certainly much stronger outside of Quebec than in this province.

\section{Labour Force Participation}

In a review of American research, it has been suggested that cohabiting couples are more likely to be non-traditional in terms of their gender-role attitudes (Seltzer, 2004). Consistent with this observation, one might expect the proportion of cohabiting women that are employed to be higher than among married women. In reviewing census data on the employment status of cohabiting women, there is clear evidence to suggest that this in true regardless of region (Table 3). This generalization also seems to apply regardless of age group or whether or not there are children in the household.

This is consistent with the idea that if women can afford it - they are often more selective in seeking a suitable spouse. Similarly, this is consistent with the idea that women in cohabiting relationships adhere to more egalitarian attitudes in terms of the labour force participation of men and women. In examining Canadian data from the early 1990s, Turcotte and Bélanger (1997) find evidence to suggest that greater financial autonomy allow women a greater freedom to choose a preferred conjugal arrangement. That is, cohabitation is more likely to express an exchange between two people who are economically independent, whereas marriage frequently implies a higher level of economic interdependency between spouses - and frequently a higher level of "economic dependency" for women. 


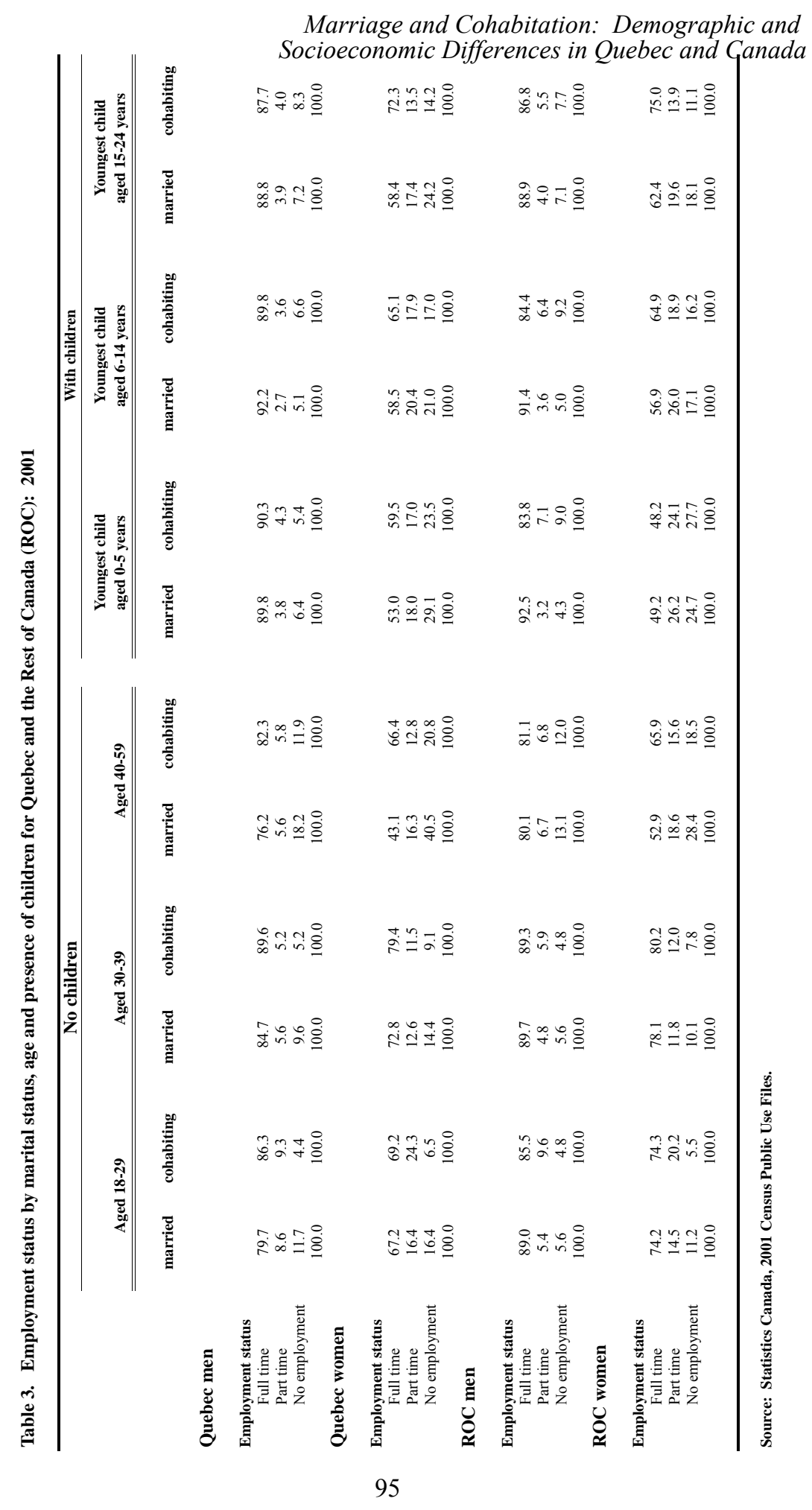


In reviewing Table 3, the differences as observed in the likelihood of employment by marital status are consistent with this idea, and are often quite large, depending upon life cycle stage and region of the country. For instance, among childless women in Quebec aged 18-29, about 16 percent of married women were not employed in 2001 which compares with only 6.5 percent of cohabiting women. Among older women aged 40-59, the difference is even more pronounced, as about 40 percent of married women are not employed relative to about 20 percent of cohabiting women. Across age and life cycle stages, married women tend to be less likely to be employed - implying a higher level of economic interdependency and a more traditional division of labour. In addition, a closer inspection of Table 3 also demonstrates how if employed, cohabiting women are more likely to be doing so on a full time rather than part time basis relative to married women.

When shifting our attention to men, the pattern again seems to be quite different, depending upon region. For example, in Quebec cohabiting men are in fact more likely than married men to be employed full time (with the exception of men who have older children). In direct contrast, outside of Quebec, cohabiting men are typically less likely to be employed full time. Again, consistent with the broader North American pattern, cohabiting men outside of Quebec are less likely to be employed full time and seem to have lower employment prospects overall. Why this is not true for men in Quebec is not altogether clear - as again, we see that socioeconomic differences are least where cohabitation has become most widespread.

\section{Median Income}

In supplementing this information on labour force participation, Figure 1a and $1 \mathrm{~b}$ provides similar breakdowns with median income. Working with this same categorization, by gender, age, marital status and the presence of children, this provides us with additional information on the economic well-being of Canadians - and how this varies by marital status. Again the situation appears to differ somewhat depending upon what part of the country we are focusing on. While median income tends to be slightly lower overall in Quebec than elsewhere, Figure 1a demonstrates how cohabiters in this province appear to be doing "relatively well".

If anything, Figure 1a demonstrates how in Quebec, women in cohabiting unions tend to report slightly higher median incomes than do married women. Among women outside of Quebec (Figure 1b), the situation seems to be quite similar, with relatively small differences between married women and cohabiters. Among men in Quebec, those who are married have a slightly higher 
Marriage and Cohabitation: Demographic and Socioeconomic Differences in Quebec and Canada

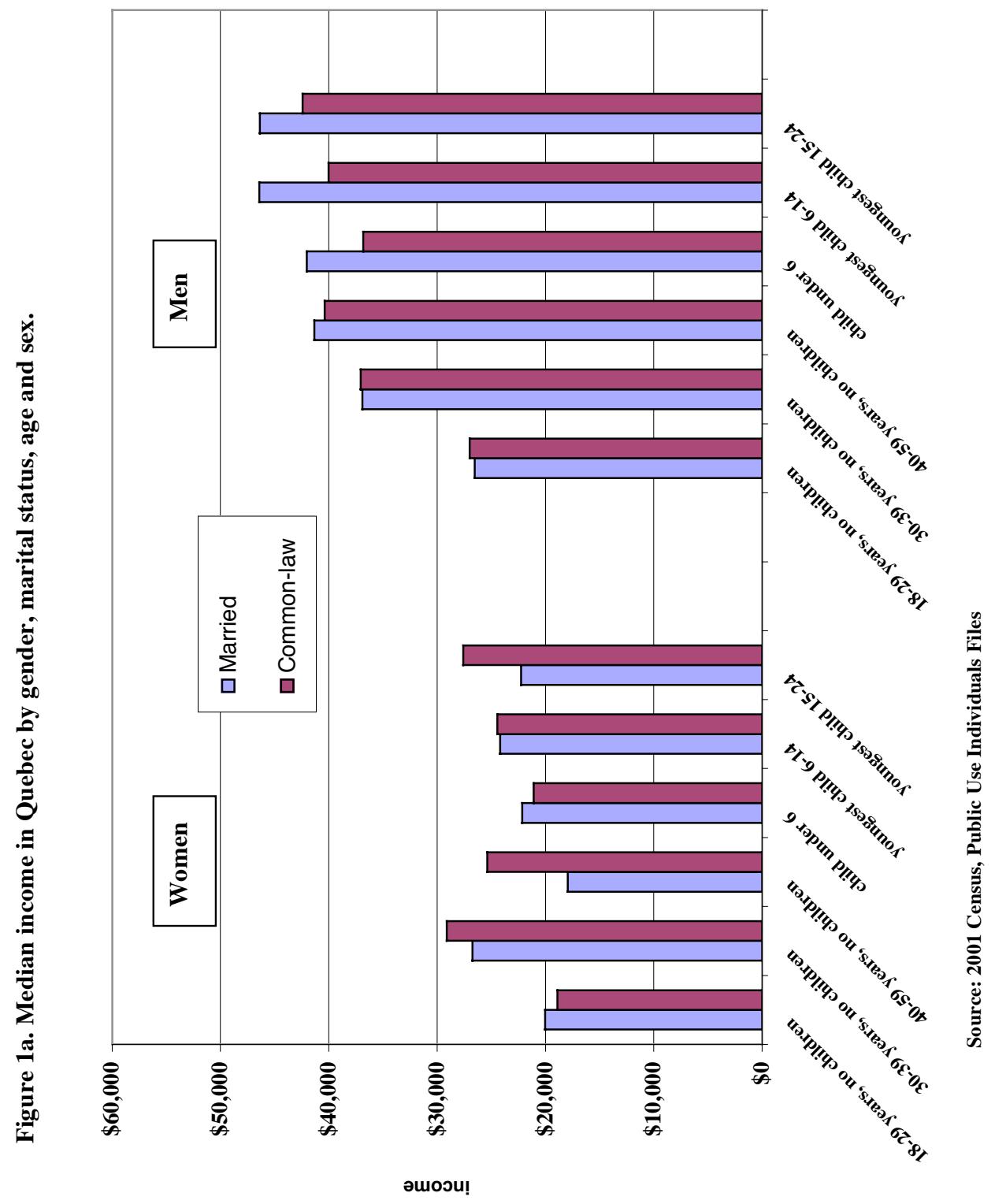




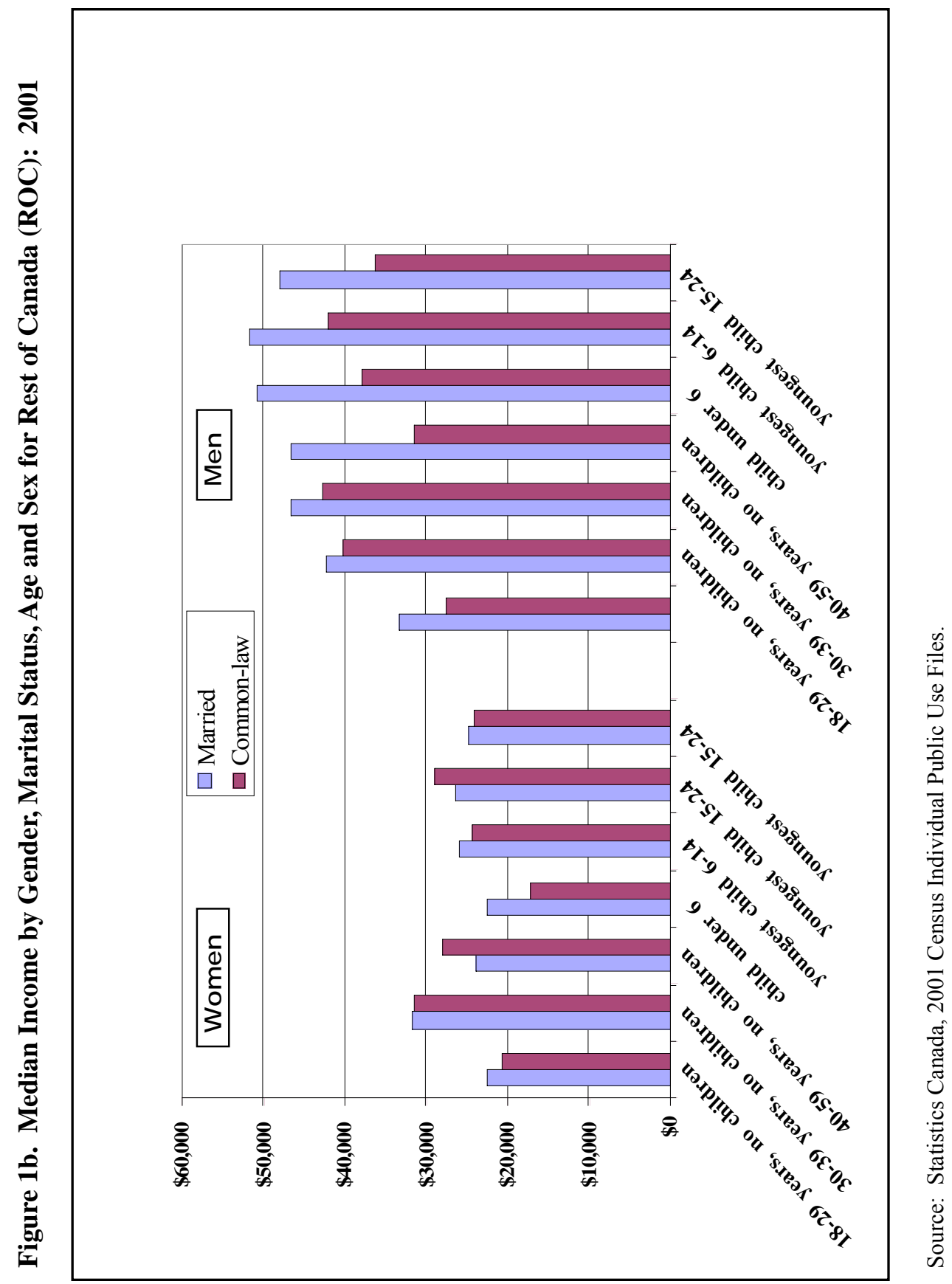


Marriage and Cohabitation: Demographic and Socioeconomic Differences in Quebec and Canada

median income, although this again varies by life cycle stage -- with virtually no differences observed for those without children. While the median income is higher in Quebec among married men, the differences by marital status are again not particularly large. Yet elsewhere in Canada, married men not only have a higher median income than cohabiters, but the differences as documented are much more pronounced. As merely an example, among men with at least one child aged $0-5$ years, the median income for married men $(\$ 50,985)$ was found to be about $34 \%$ higher than for cohabiting men $(\$ 37,908)$. In making this same comparison for Quebec, the difference as observed was not nearly as large (at about 14 percent) with medians of $\$ 42,029$ and $\$ 36,814$ respectively.

These differences are consistent with the idea that the impact of a man's economic prospects play out in a different manner than those of a woman's. In particular, the difficulty of integrating into the labour force and obtaining a reasonable salary may make marriage more difficult for men, while possibly having a lesser impact on women. To the extent that the decision to marry might be influenced by traditional gender roles, a lower income and weaker job prospects might have a greater impact on the ability of men to establish longer term relationships than it would have on the ability of women to do so. In addition, some of the greatest differences, particularly for men outside of Quebec, were documented for those with children, which suggest a potential interaction with marital status in influencing the decision to marry. With children, it is possible that women may be even less likely to formalize a relationship via marriage if their partner earns a relatively low wage.

\section{Incidence of Low Income}

Figures $2 \mathrm{a}$ and $2 \mathrm{~b}$ provides information on the percentage of persons classified as 'low income' in 2001 (using Statistics Canada's 1992 base LICOs - before tax). More specifically, this figure demonstrates how the likelihood of low income varies by marital status, just as it varies across the above demarcated life cycle stages. For example, parents with particularly young children (aged 0-5 years) are more likely than most to experience low income (in both Quebec and elsewhere), although this might be said to be particularly true among cohabiting parents outside of Quebec. Low income rates among these cohabiting men and women outside of Quebec approach 25 percent - whereas in the province of Quebec, these rates are at about 15 to 16 percent. Some of these differences as observed outside of Quebec are rather striking - and are completely consistent with the idea that cohabitation is associated with more uncertain economic prospects. 


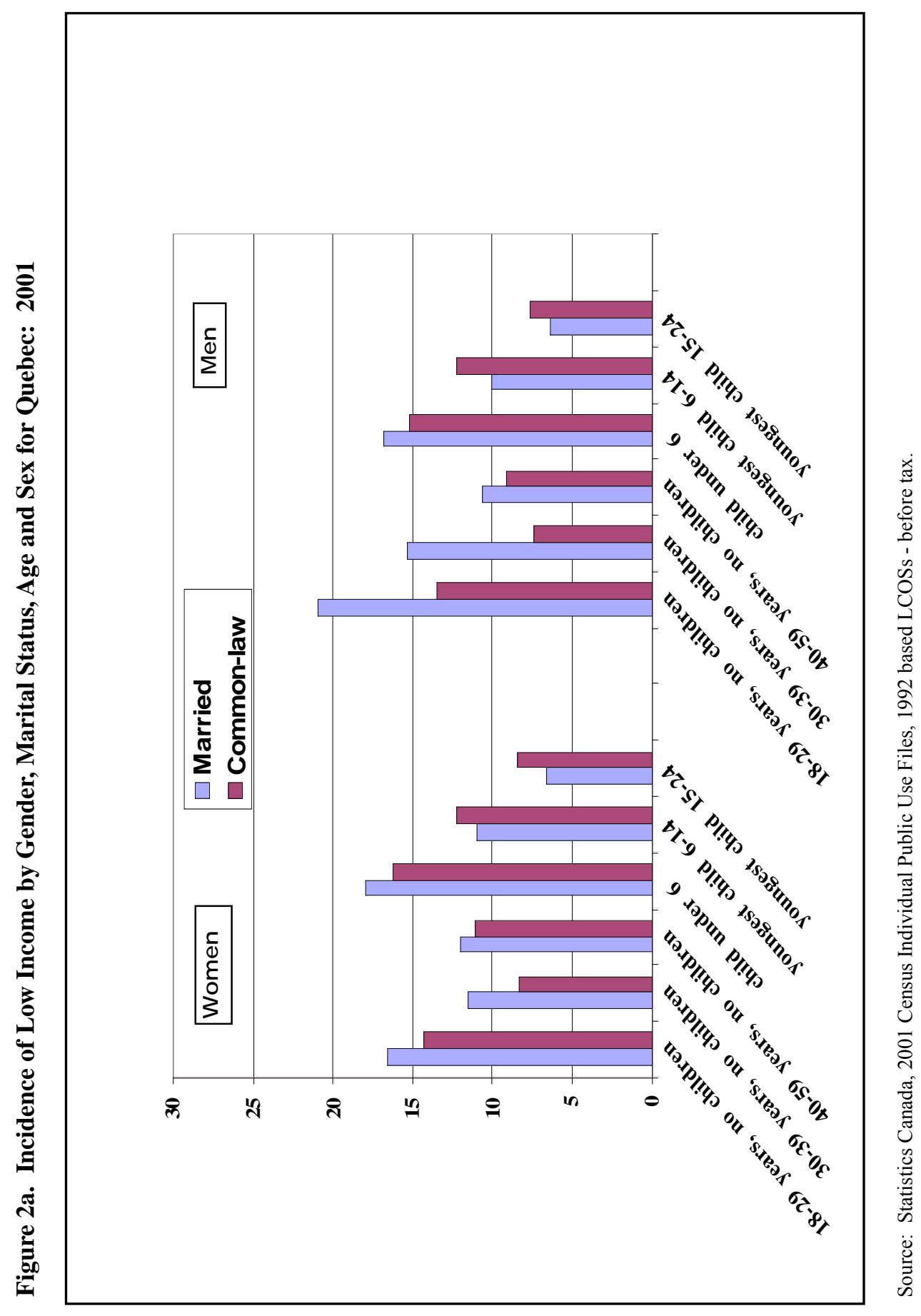


Marriage and Cohabitation: Demographic and Socioeconomic Differences in Quebec and Canada

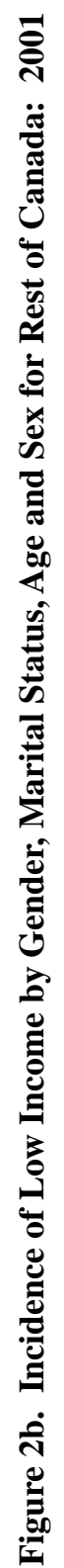

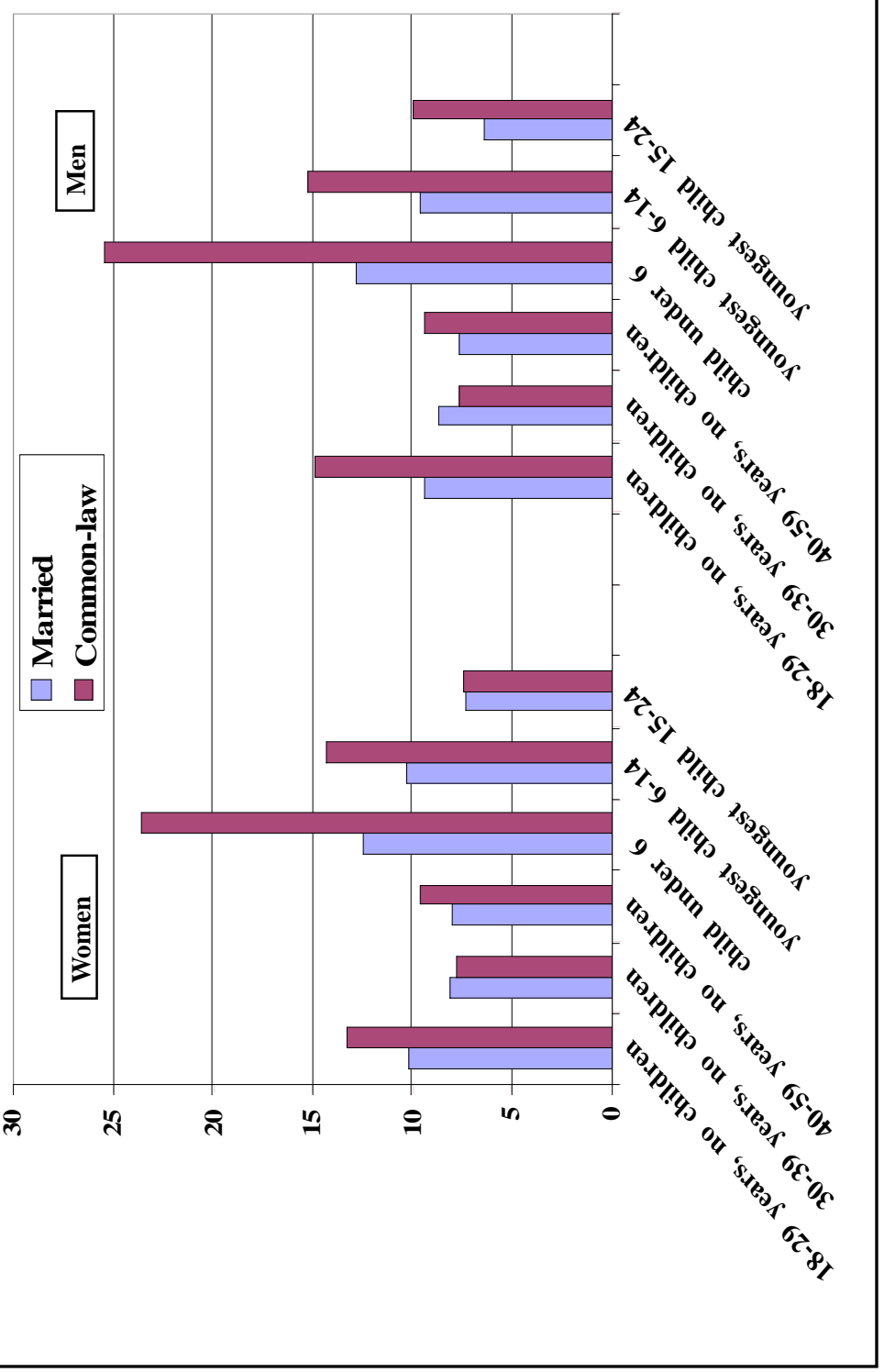

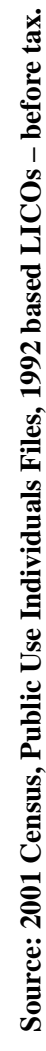


In comparing the situation in Quebec with what is observed elsewhere, not only are there important differences by life cycle stage, but more generally, the overall pattern of low income by marital status actually appears to reverse itself. While cohabiting adults are more likely to experience income poverty throughout most of Canada, cohabiting unions in Quebec actually have slightly lower levels overall. An exception to this general rule relates to the parents of older children, where low income rates are slightly higher among cohabiters, regardless of region. Where cohabitation is most widespread, common law unions do not appear to be particularly disadvantaged - at least in terms of low income rates documented via the census. While persons living common law appear to be slightly less likely to experience income poverty in Quebec, the situation outside of Quebec seems to fall in line with the broader North American pattern - with higher poverty rates associated with cohabitation.

\section{Homeownership}

Homeownership is distinguished from renting by the considerable long-term financial responsibility that it entails. The purchase of a residence involves a sizable portion of an average household's wealth and, therefore, typically requires financing in the form of a mortgage (Dietz \& Haurin, 2003). It also involves relatively high transaction costs associated with which tends to deter geographic mobility (Feijten, 2003). Entry into homeownership, then, is governed by both the present and the prospective socioeconomic resources of those involved (Feijten et al., 2003).

Besides socioeconomic resources, homeownership reflects the stability of the household, including the relationship stability of the co-residential, conjugal couple. In light of such responsibilities, it is logical that individuals are more hesitant to purchase an owner-occupied residence when they perceive that the future of their relationship is uncertain. Given that socioeconomic resources and relationship stability govern entry into homeownership, it is logical that the prevalence of homeownership according to marital status reflects differences their socioeconomic resources and relationship stability.

Returning to our data from the 2001 census, we find that, in general, women and men in Quebec (Figure 3a) and the rest of Canada (Figure 3b) are more likely to be homeowners if they are married rather than in a common-law union. Yet in considering regional differences in homeownership by marital status, the disparity in homeownership is clearly much less in Quebec than in the rest of Canada. The popularity of common-law unions in Quebec likely contributes to this lesser disparity, as does the aforementioned evidence that socioeconomic differences between common law unions and marriages are less than elsewhere. 
Marriage and Cohabitation: Demographic and Socioeconomic Differences in Quebec and Canada

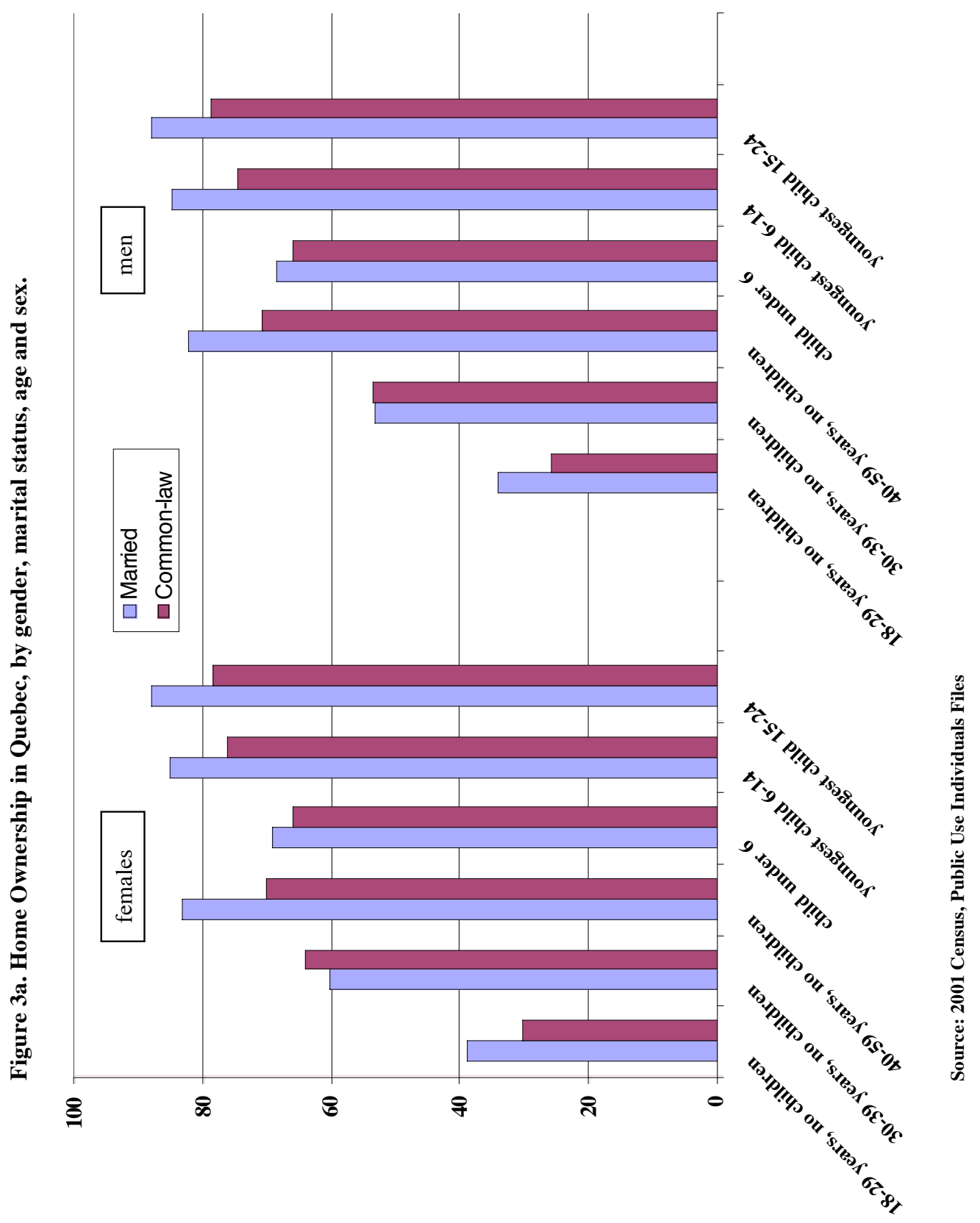




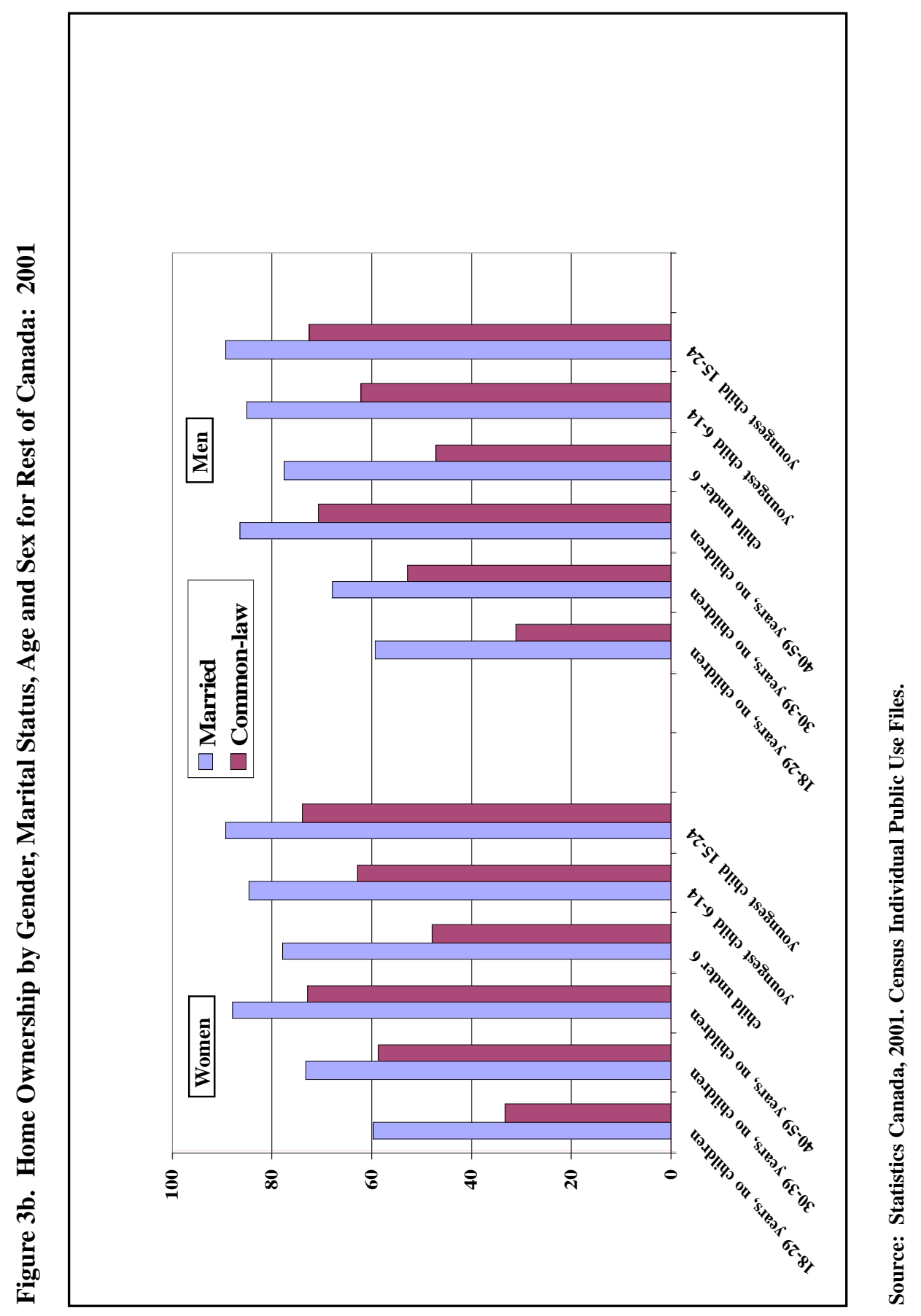


Marriage and Cohabitation: Demographic and Socioeconomic Differences in Quebec and Canada

In addition, to the extent that common law unions are slightly more stable in Quebec whereas the divorce rate is slightly higher, one might expect that these disparities in homeownership by marital status decline.

\section{The Organization of Daily Life}

Both common-law unions and marriages share a common function: i.e. they both involve the sharing and maintenance of a household between intimate partners. This maintenance of a household obviously necessitates that (i) domestic tasks be accomplished, and (ii) that an adequate income be obtained in order to maintain a reasonable standard of living. In so doing, the division of labour in conjugal unions depends on social norms about the appropriate work for men and women. Historically, the division of labour was highly gendered in Canada, although this is obviously much less so the case today then it was a few decades ago (Beaujot, 2000; Beaujot and Ravanera, 2005).

In this context, it is interesting to ask whether common law unions are more egalitarian than marriages, in the sharing of work both within and outside of the home. Insofar as cohabitation is an incomplete institution, the organization of daily life around the division of labour is likely less governed by social norms, which might lead to greater room to negotiate a division of labour that is less traditional and gendered.

While common-law unions differ from married couples in terms of their division of paid labour, past research has not documented big differences in terms of their unpaid labour, or the amount of time they spent on housework. For example, Shelton and John (1993) find that marital status among American couples affected the amount of time spent on domestic activities by women, but not by men. In turning our attention to time use data coming out of the Canadian General Social Survey (1998), Table 4 demonstrates a relatively high level of consistency across marital statuses in the amount of time women and men spend on domestic labour, i.e. those in common law unions spend virtually the same among of time on domestic labour as do their married counterparts - true of both couples with and without children. Canadian women spend nearly double the amount of time that men do on housework, regardless of whether they are cohabiting or married. The division of domestic labour between partners, then, is gendered in both common-law unions and marriages, to the extent that women continue to take on a larger share of unpaid work and men continue to take on a larger share of paid work. 
Don Kerr, Melissa Moyser and Roderic Beaujot

Table 4

Time Use (Average Hours per Day) of Population Aged 49 years and Less by Marital and Parental Status, for Canada, Quebec and Rest of Canada: 1998

\begin{tabular}{|c|c|c|c|c|c|c|c|c|}
\hline & \multicolumn{2}{|c|}{$\begin{array}{l}\text { Common-Law } \\
\text { no children }\end{array}$} & \multicolumn{2}{|c|}{$\begin{array}{c}\text { Married } \\
\text { no children }\end{array}$} & \multicolumn{2}{|c|}{$\begin{array}{l}\text { Common-law } \\
\text { Parents }\end{array}$} & \multicolumn{2}{|c|}{$\begin{array}{c}\text { Married } \\
\text { Parents }\end{array}$} \\
\hline & Men & Women & Men & Women & Men & Women & Men & Women \\
\hline \multicolumn{9}{|l|}{ Canada } \\
\hline Paid Work and/or Education & 6.8 & 5.2 & 6.8 & 5.3 & 6.2 & 3.4 & 6.7 & 3.8 \\
\hline Domestic Labour & 1.3 & 2.2 & 1.4 & 2.3 & 2.7 & 4.8 & 2.5 & 4.8 \\
\hline Personal Care & 0.9 & 10.7 & 9.9 & 10.5 & 9.7 & 10.1 & 9.7 & 10.1 \\
\hline Shopping & 0.8 & 0.9 & 0.7 & 0.8 & 0.4 & 1.1 & 0.6 & 1.0 \\
\hline Leisure/Free Time & 5.4 & 5.0 & 5.2 & 5.0 & 4.9 & 4.5 & 4.4 & 4.3 \\
\hline Total & 24.0 & 24.0 & 24.0 & 24.0 & 24.0 & 24.0 & 24.0 & 24.0 \\
\hline \multicolumn{9}{|l|}{ Quebec } \\
\hline Paid Work and/or Education & 7.2 & 4.5 & 5.8 & 4.2 & 5.7 & 2.9 & 6.4 & 4.2 \\
\hline Domestic Labour & 1.3 & 2.5 & 1.9 & 2.8 & 3.1 & 4.8 & 2.6 & 4.4 \\
\hline Personal Care & 10.2 & 10.9 & 10.2 & 10.7 & 10.1 & 10.7 & 10.1 & 10.4 \\
\hline Shopping & 0.4 & 0.9 & 0.6 & 1.0 & 0.4 & 1.1 & 0.6 & 0.9 \\
\hline Leisure/Free Time & 4.8 & 5.3 & 5.5 & 5.6 & 4.6 & 4.5 & 4.3 & 4.1 \\
\hline Total & 24.0 & 24.0 & 24.0 & 24.0 & 24.0 & 24.0 & 24.0 & 24.0 \\
\hline \multicolumn{9}{|l|}{ Rest of Canada } \\
\hline Paid Work and/or Education & 6.6 & 5.6 & 7.1 & 5.5 & 7.0 & 4.0 & 6.8 & 3.8 \\
\hline Domestic Labour & 1.3 & 2.0 & 1.2 & 2.3 & 2.2 & 4.9 & 2.6 & 4.9 \\
\hline Personal Care & 9.6 & 10.6 & 9.9 & 10.5 & 9.0 & 9.6 & 9.6 & 10.0 \\
\hline Shopping & 0.8 & 0.9 & 0.7 & 0.8 & 0.4 & 1.0 & 0.7 & 1.0 \\
\hline Leisure/Free Time & 5.7 & 4.9 & 5.1 & 4.9 & 5.4 & 4.6 & 4.4 & 4.4 \\
\hline Total & 24 & 24 & 24 & 24 & 24 & 24 & 24 & 24 \\
\hline
\end{tabular}

Source : 1998 General Social Survey, Public Use Files. 
Marriage and Cohabitation: Demographic and Socioeconomic Differences in Quebec and Canada

With regard to regional differences, Table 4 suggests that the gender differences in the amount of time spent on domestic labour per day may actually be slightly less in Quebec than elsewhere in Canada. Yet these differences are not particularly pronounced and this largely applies to couples with children. More importantly, it is the presence of children that seems to be far more important in predicting the degree to which couples share domestic responsibilities. Gender differences in the time devoted to unpaid work are greater for couples with children than for childless couples, regardless of marital status and region. To the extent that the performance of housework implies conformity to traditional gender roles and contributes to the definition of traditional gender identities - the division of domestic labour between couples in both marriages and common-law unions continue to be "very much gendered" in this regard.

\section{Discussion and Conclusion}

In light of its importance to public policy, there has been a strong interest in understanding the extent to which marriage and cohabitation differ, and the extent they might be treated differently by legislators and the Canadian legal system. This is not an easy question to answer because the very meaning of cohabitation differs over time and space. The meaning of cohabitation can even differ over time for a given couple. Marriage itself is changing, rather than providing a stable point of reference. The family change of the second demographic transition has especially been measured by the greater flexibility in the forms of entry and exit from unions. The changes in these measurable aspects of marital unions are thought to be a reflection of changes in unions themselves, including the de-institutionalization and an individualization of relationships. Roussel (1989), a French sociologist of the family, has spoken of a change from marriages that need to conform to certain norms, to a "projet de couple" defined by the participants themselves.

While individualization and diversity are all well and good, Canadian public policy needs to treat given types of relationships in equivalent ways. This especially applies to relations that include children, since it is the most vulnerable who are in strongest need of protection. Even if there are no children, unions often include dependency, and a consequent need to protect persons who are dependent. Particularly in the context of specialization and complementarity in the division of the labour associated with earning a living and caring for each other, a strong marriage contract is needed to protect persons who are economically dependent because they have specialized in caring. We have evolved a welfare state where the family is often the first line of defence when individuals are not self-sufficient, due to disability, youth or age. This includes the contradiction that the family member who cares for others can devote 
themselves less to earning a living and thus lose their own self-sufficiency. Consequently, many marital relationships include dependency, and a need to protect the persons who are dependent. A crucial question is to know whether marriage and cohabitation are similar in terms of these dynamics of dependency.

Given the aforementioned differences between Quebec and the rest of Canada, our comparisons on the socioeconomic characteristics of persons who marry and cohabit have also been made separately for these two parts of the country. In making socio-economic comparisons, we have also controlled for gender and the life cycle stage, differentiating by the age of the youngest child. For those without children, we have differentiated by age of respondent. These differences in socio-economic status are difficult to summarize. The differences are typically smaller in Quebec, where cohabiters are more likely to show stronger labour force participation, lower income poverty and higher incomes. Outside of Quebec, it is the married men that typically have higher participation and income than the cohabiting men.

In other words, cohabitation in Quebec appears to take on quite a different character than cohabitation elsewhere, making generalizations difficult. Throughout most of Canada, marriage appears to be somewhat selective of higher status, especially for men. Men with lower status would be less desirable as marriage partners. Under such circumstances, marriage may very well bring a greater division of labour, since the men with higher status take more responsibility for earning a living. On the other hand, cohabitation seems to be more of a "real choice" in Quebec, and may signal greater departure from a traditional division of labour, especially for women. Cohabitation would then imply less differentiation between women and men, or it would be selective of women with higher socio-economic status compared to married women. As a result, where cohabitation is most widespread, the characteristics of cohabiters do not differ dramatically from the characteristics of those that marry. Similarly in Quebec, cohabitation is more similar to marriage as it is much more likely to involve children than elsewhere in Canada, just as it is more likely to be stable and of longer duration.

Whether it be cohabiting or married couples, in Quebec or outside of Quebec, children bring a greater differentiation in the division on labour, with women doing more of the unpaid work. As both common law men and women are more likely to be employed in Quebec than are their married counterparts, this is further evidence to suggest that relationships in Quebec are more likely to depart from a traditional division of labour. Yet the evidence is not straightforward, as our data on the division of domestic tasks suggest relatively minor differences between cohabiting and married couples, regardless of region. While marriage is more likely to be linked with a traditional division of labour, our evidence on 
Marriage and Cohabitation: Demographic and Socioeconomic Differences in Quebec and Canada

time use within Canadian households suggests that we should not overstate the relevance of marital status in predicting the division of domestic tasks. What is particularly relevant in this context is whether or not a couple has children.

If cohabitation involves less dependency, there is less need for legal protection. However, given especially the gender differences in incomes, many cohabiting couples include dependent relationships, and associated needs for legal protection. It can be argued that children's lives have especially been affected by the greater flexibility in the entry and exit from unions. Since the presence of children brings greater inequality in the division of work, legal protection is especially needed when there are children, regardless of the nature of the marital union, possibly especially in the case of cohabiting unions which are more likely to be of shorter duration.

As we opt for a society where there are fewer dependencies, and more equality between men and women, it is useful to take note of other legal provisions that remain based on a traditional breadwinner model. This may apply to widowhood benefits, pension splitting and tax deductions for a dependent spouse. While these provisions are a means of accommodating dependency in couples, they can also discourage rather than promote the economic independence of women and men. Similarly, poorly subsidized parental leave, and lack of benefits for parttime work, can reduce the likelihood that couples will share the leaves and parttime work associated with childbearing, as they seek to maximize the family income. Making joint custody the default condition, would also signal the continuing responsibility of both parents for the well-being of children. Joint custody would also signal that separations involve the link between adults, rather than the links between adults and children.

\section{Acknowledgements:}

The authors wish to acknowledge Justice Canada for funding provided for this paper. Justice Canada is not responsible for the views and opinions expressed in this paper. 
Don Kerr, Melissa Moyser and Roderic Beaujot

End Notes:

1. In comparing persons with and without children (present in the home), these categories are not strictly comparable in terms of stage in the life cycle. In the case of persons without children, we consider exclusively birth cohorts, whereas among those with children we consider the age of the youngest child in classification rather than birth cohort.

2. The sample selected from the census for the public use file is extremely large, with fully $2.7 \%$ of all persons enumerated in the 2001 census selected (or over 800,000 individuals). For this reason, the level of precision in Tables 1-3 is very high, with even relatively small differences statistically significant.

\section{References:}

Amato, Paul R. and Stacy J. Rogers. 1999. "Do Attitudes Toward Divorce Affect Marital Quality?" Journal of Family Issues, 20: 69-86.

Ambert, Anne-Marie. 2002. Divorce: Facts, causes and consequences. Ottawa: The Vanier Institute of the Family.

Ambert, Anne-Marie. 2006. Changing Families: Relationships in Context. Toronto: Pearson Allyn \& Bacon Inc.

Axinn, William G. and Arland Thornton. 1992. "The Relationship between Cohabitation and Divorce: Selectivity or Causal Influence?" Demography, 29: 357-374.

Bachrach, Christine A. 1987. "Cohabitation and Reproductive Behavior in the U.S.” Demography 24: 623-637.

Barrere-Maurisson, Marie-Agnes. 1995 "Regulation familiale, marchande ou politique: les variations de la relation travail-famille. Sociologie et Societes, 27 :69-85.

Beaujot, Roderic. 1999. "Demographics and the changing Canadian family." Paper prepared for Research and Statistics Division, Justice Canada.

Beaujot, Roderic. 2000. Earning and Caring in Canadian Families. Peterborough: Broadview Press. 
Marriage and Cohabitation: Demographic and Socioeconomic Differences in Quebec and Canada

Beaujot, Roderic. 2004._Delayed Life Transitions: Trends and Implications. Ottawa: Vanier Institute of the Family.

Beaujot, Roderic and Don Kerr. 2004. Population Change in Canada. Don Mills: Oxford University Press.

Beaujot, Roderic and and Jianye Liu. 2005. "Models of Time Use in Paid and Unpaid Work." Journal of Family Issues, (forthcoming)

Beaujot, Roderic and Zenaida R. Ravanera. 2005. Family Models for Earning and Caring: Implications for Parents and Children. Discussion Paper, Population Studies Centre, University of Western Ontario.

Booth, A. and A. Crouter. 2002. Just Living Together: Implications of Cohabitation on Families, Children and Social Policy. Mahwah: Lawrence Erlbaum Associates.

Brines, Julie and Kara Joyner. 1999. "The Ties That Bind: Principles of Cohesion in Cohabitation and Marriage." American Sociological Review, 64: 333-355.

Blumstein and Swartz, 1983. American Couples. New York: William Morrow.

Brown, Susan L. 2003. "Relationship Quality Dynamics of Cohabiting Unions." Journal of Family Issues, 25: 583-601.

Brown, Susan L. and Alan Booth. 1996. "Cohabitation Versus Marriage: A Comparison of Relationship Quality." Journal of Marriage and the Family, 58: 668-678.

Bumpass, L and H, Lu. 2000. "Trends in Cohabitation and Implications for Children's Family Contexts.” Population Studies, 54: 29-41.

Chafetz, Janet Saltzman. 1995. "Chicken or Egg? A Theory of the Relationship between Feminist Movements and Family Change," in Gender and Family Change in Industrialized Countries, edited by Karen Oppenheim Mason and An-Magritt Jensen. Oxford: Clarendon Press, pp. 63-81.

Cherlin, Andrew J. 2004. "The Deinstitutionalization of American Marriage." Journal of Marriage and the Family, 66: 848-861. 
Don Kerr, Melissa Moyser and Roderic Beaujot

Clarkberg, Marin, Ross M. Stolzenberg, and Linda J. Waite. 1995. "Attitudes, Values, and Entrance into Cohabitational versus Marital Unions.” Social Forces, 74: 609-34.

Desrosiers, Helene. et Celine Le Bourdais, 1996. « Progression des unions libres et avenir des familles biparentales » Recherches féministes, 9: 65-84.

DeMaris, A. \& MacDonald, W. 1993. Premarital cohabitation and marital instability: A test of the unconventionality hypothesis. Journal of Marriage and the Family, 55: 399-407.

Dietz, Robert D. and Donald R. Haurin. 2003. "The social and private microlevel consequences of homeownership." Journal of Urban Economics, 54: 401-450.

Drolet, Marie. 2003. Motherhood and Paycheques. Canadian Social Trends, 68: 19-21.

Duchesne, L. 2003. La situation démographique au Québec, bilan 2003. Québec: Institut de la statistique du Québec.

Dumas, Jean and Alain Bélanger. 1997. Report on the Demographic Situation in Canada 1996. Ottawa: Statistics Canada, Catalogue No. 91-209-XPE.

Dush, Claire M. Kamp, Catherine L. Cohan, and Paul R. Amato. 2003. "The Relationship Between Cohabitation and Marital Quality and Stability: Change Across Cohorts?" Journal of Marriage and the Family, 65: 539549.

Espenshade, T. 1979. "The Economic Consequences of Divorce.” Journal of Marriage and the Family, 41: 615-625.

Feijten, Peteke, Clara H. Mulder, and Pau Baizán. 2003. “Age Differentiation in the effect of household situation of first-time homeownership." Journal of Housing and the Built Environment, 18: 233-255.

Freidan, Betty. 1963. The Feminine Mystique. New York: Norton.

Gupta, Sanjiv. 1999. “The Effects of Transitions in Marital Status on Men's Performance of Housework." Journal of Marriage and the Family, 61: 700-711. 
Marriage and Cohabitation: Demographic and Socioeconomic Differences in Quebec and Canada

Hakim, Catherine. 2000. Work-Lifestyle Choices in the $21^{\text {st }}$ Century: Preference Theory. Oxford: Oxford University Press.

Heimdal, Kristen R. and Sharon K. Houseknecht. 2003. "Cohabiting and Married Couples' Income Organization: Approaches in Sweden and the United States." Journal of Marriage and the Family, 65: 525-538.

Heuveline, P., Timberlake, J. M., \& Furstenberg, F. F., Jr. 2003. Shifting childrearing to single mothers: Results from 17 Western countries. Population and Development Review, 29, 47-71.

Hirschman, Charles. 1994. "Why Fertility Changes." Annual Review of Sociology. 20:203-233.

Kersten, Karen and Lawrence Kersten, 1991. "A Historical Perspective on Intimate Relationships," In Jean Veevers, ed., Continuity and Change in Marriage and Family. Toronto: Holt, Rinehart and Winston.

Kiernan, Kathleen. 2002. "Cohabitation in Western Europe: Trends, Issues, and Implications," in Just Living Together: Implications of Cohabitation on Families, Children, and Social Policy, edited by Alan Booth and Ann C. Crouter. Mahwah: Lawrence Erlbaum Associates, pp. 3-31.

Lapierre-Adamcyk, Évelyne. 1987. “Mariage et politique de la famille.” Paper Presented at the Meetings of the Association des Démographes du Québec. Ottawa.

Le Bourdais, Céline and Heather Juby. 2002. "The Impact of Cohabitation on the Family Life Course in Contemporary North America: Insights From Across the Border," in Just Living Together: Implications of Cohabitation on Families, Children, and Social Policy, edited by Alan Booth and Ann C. Crouter. Mahwah: Lawrence Erlbaum Associates, pp. 107-118.

Le Bourdais, Céline and Évelyne Lapierre-Adamcyk. 2004. "Changes in Conjugal Life in Canada: Is Cohabitation Progressively Replacing Marriage?" Journal of Marriage an the Family, 66: 929-942.

Lefebvre, Pierre and Philip Merrigan. 1997. Family Background, Family Income, Maternal Work and Child Development No. W-98-12E. Applied Research Branch, Human Resources Development Canada. 
Don Kerr, Melissa Moyser and Roderic Beaujot

Lero, Donna S. 1996. "Dual-Earner Families," in Voices: Essays on Canadian Families, edited by Marion Lynn. Scarborough: Nelson Canada. Pp. 20-53

Lesthaeghe, R. 1995. "The Second Demographic Transition in Western Countries: An Interpretation," in Gender and Family Change in Industrialized Countries, edited by Karen Oppenheim Mason and AnMargritt Jensen. Oxford: Claredon Press, pp. 17-62.

Lesthaeghe, Ron and Johan Surkyn. 2004. "When history moves on: The foundations and diffusion of a second demographic transition." Paper Presented at the $12^{\text {th }}$ Biennial Conference of the Australian Population Association. Canberra, Australia.

Lesthaeghe, R and D.J. van de Kaa (1986) "Twee demografische transitiesin Bevolking: Groei en Krimp, edited by D.J. van de Kaa and R. Lesthaeghe. Deventer: Van Loghum Slaterus.," pp. 19-68.

Manting, D. (1996). The changing meaning of cohabitation and marriage. European Sociological Review, 12, 53-65

Marcil-Gratton, Nicole and Céline Le Bourdais. 1999. Custody, Access and Child Support : Findings from The National Longitudinal Survey of Children and Youth. Ottawa: Department of Justice Canada.

Moors, Guy. 2003. "Estimating the Reciprocal Effect of Gender Role Attitudes and Family Formation: A Log-linear Path Model with Latent Variables." European Journal of Population 19: 199-221.

Morissette, René. 1998. The Declining Labour Market Status of Young Men. In M. Corak, Editor, Labour Markets, Social Institutions and the Future of Canada's Children. Ottawa: Statistics Canada, cat. no. 89-553.

Nock, Steven L. 1995. "A Comparison of Marriages and Cohabiting Relationships.” Journal of Family Issues, 16: 53-76.

Naiman, Joanne. 2000. How Societies Work: Class, Power and Change in a Canadian Context. Toronto: Irwin Publishing.

Picot, Garnett.1998. What is Happening to Earnings Inequality and Youth Wages in the 1990s. Canadian Economic Observer, 11: 1-3.18. 
Marriage and Cohabitation: Demographic and Socioeconomic Differences in Quebec and Canada

Raley, R. Kelly. 2001. "Increasing Fertility in Cohabiting Unions: Evidence for the Second Demographic Transition in the United States?" Demography, 38: 59-66.

Ram, Bali. 2002. "Children in Common-Law Unions: The Canadian Experience." Paper Presented at the XV World Congress of Sociology. Brisbane, Australia.

Rousell, Louis. 1989. La famille incertaine. Paris: Editions Odile Jacob.

Ryder, Norman. 1983. "Cohort and Period Measures of Changing Fertility," In R. Bulatao and R. Lee (eds.) Determinants of Fertility in Developing Countries. Vol 2. New York: Academic, pp. 737-756.

Scanzoni, Letha and John Scanzoni. 1976. Men, Women, and Change: A Sociology of Marriage and the Family. New York: McGraw-Hill.

Seltzer, Judith A. 2004. "Cohabitation and Family Change," in Handbook of Contemporary Families: Considering the Past, Contemplating the Future, edited by Marilyn Coleman and Lawrence H. Ganong. Thousand Oaks: Sage Publications, Inc., pp. 57-78.

Shelton, Beth Anne and Daphne John. 1993. "Does Marital Status Make a Difference? Housework Among Married and Cohabiting Men and Women." Journal of Family Issues, 14: 401-420.

Skolnick, Arlene. 1987. The Intimate Environment. Boston: Little, Brown.

Smock, Pamela J. 2000. "Cohabitation in the United States: An Appraisal of Research Themes, Findings, and Implications." Annual Review of Sociology, 26: 1-20.

Smock, Pamela and Sanjiv Gupta 2002. In Booth, A. and A. Crouter. eds. Just Living Together: Implications of Cohabitation on Families, Children and Social Policy. Mahwah: Lawrence Erlbaum Associates, pp. 53-84.

Smock, Pamela J. and Wendy D. Manning. 2004. "Living Together Unmarried in the United States: Demographic Perspectives and Implications for Family Policy." Law and Policy, 26: 87-117.

South, Scott J. and Glenna Spitze. 1994. "Housework in Marital and Nonmarital Households." American Sociological Review, 59: 327-347. 
Don Kerr, Melissa Moyser and Roderic Beaujot

Stanley, Scott M., Sarah W. Whitton, and Howard J. Markman. 2004. "Maybe I Do: Interpersonal Commitment and Premarital or Nonmarital Cohabitation." Journal of Family Issues, 25: 496-519.

Statistics Canada. 2001. Changing Conjugal Life in Canada. Ottawa: Statistics Canada, Catalogue No. 89-576-XIE.

Statistics Canada, 2002. Divorces. Ottawa: Statistics Canada, Catalogue No. 84F0213XPB.

Statistics Canada, 2003. Profile of Canadian Families and Households: Diversification Continues. Statistics Canada, cat. No. 96F0030XIE2002003.

Statistics Canada, 2004. The Canada E-Book. Ottawa. Statistics Canada, Catalogue No. 11-404-XIE.

Statistics Canada, 2004. Births, 2002. Ottawa: Statistics Canada, Catalogue No. 84F0210XIE.

Trost, Jan. 1986, "What Holds Marriage Together," in J. Veevers, ed. Continuity and Change in Marriage and Family. Toronto: Holt, Reinhart and Winston.

Turcotte, Pierre, \& Bélanger, Alain (1997). The dynamics of formation and dissolution of first common-law unions in Canada. Ottawa, Ontario: Statistics Canada.

Turcotte, Pierre and Frances Goldscheider. 1998. The Evolution of Factors Influencing First Union Formation in Canada. Canadian Studies in Population, 25, 2: 145-174.

U.S. Bureau of the Census. 1999. Historical Estimates of Cohabitation. Washington: Population Division Working Paper No. 36.

van de Kaa, Dirk J. 2002. "The Idea of a Second Demographic Transition in Industrialized Countries." Paper Presented at the $6^{\text {th }}$ Welfare Policy Seminar of the National Institute of Population and Social Security. Tokyo, Japan.

Veevers, Jean. 1980. Childless by Choice. Toronto: Butterworths. 
Marriage and Cohabitation: Demographic and Socioeconomic Differences in Quebec and Canada

Villeneuve-Gokalp C. 1990. Du mariage aux unions sans papiers: histoire recente des transformations conjugales, Population, 45 :265-298.

Waite, Linda . 1995. "Does Marriage Matter?" Demography, 32:489-507.

West, Candace and Don H. Zimmerman. 1987. "Doing Gender." Gender and Society, $1: 125-155$.

Westoff, Charles. 1986. "Perspectives on Nuptiality and Fertility." Population and Development Review, 12, Supplement: 155-170.

Wilson, Susannah. 1990. “Alternatives to Traditional Marriage.” In M. Baker, Families: Changing Trends in Canada. Toronto: McGraw-Hill.

Wu, Zheng. 2000. Cohabitation: An Alternate Form of Family Living. Toronto: Oxford University Press.

Wu, Zheng and T.R. Balakrishnan, 1995. Dissolution of premarital cohabitation in Canada. Demography, 32, 521-532.

Wu, Zheng and Michael Pollard. 2000. "Economic Circumstances and the Stability of Non-marital Cohabitation." Journal of Family Issues, 21: 303-328. 